\title{
New record of Alopias superciliosus Lowe, 1841 in the North-Western Mediterranean and annotated review of the Mediterranean records
}

\author{
Luca LANTERI $^{1 *}$, Laura CASTELLANO ${ }^{2}$ and Fulvio GARIBALDI ${ }^{1}$ \\ ${ }^{1}$ DISTAV - Dipartimento di Scienze della Terra, dell'Ambiente e della Vita, University of Genoa, \\ Corso Europa 26 - 16132 Genova, Italy \\ ${ }^{2}$ Aquarium of Genoa - Area Porto Antico, Ponte Spinola - 16128 Genova, Italy \\ *Corresponding author, e-mail: luca.lanteri@libero.it
}

On 9th September 2015 the head of a shark belonging to the genus Alopias, was landed at Camogli harbour in the Ligurian Sea (North Western Mediterranean). The specimen has been caught 16 miles far from the coast $\left(44^{\circ} 06^{\prime} \mathrm{N}, 008^{\circ} 57^{\prime} \mathrm{E}\right)$ as by-catch of the mesopelagic swordfish longline, but only the head was recovered, due to the predatory/scavenging activity by other shark specimens. The specimen was a female of big-eye thresher shark Alopias superciliosus a highly migratory species worldwide distributed in tropical and temperate waters but rarely caught in the Mediterranean Sea. The present record is the northenmost reported for this species in the Mediterranean area and the sixth in Italian waters

Key words: Alopias superciliosus, Ligurian Sea, Mediterranean Sea, by catch, longline

\section{INTRODUCTION}

The bigeye thresher shark Alopias superciliosus Lowe, 1841 is a highly migratory species distributed in tropical and temperate waters (FROSE \& PAULY, 2015), listed as "vulnerable" on the IUCN Red List due to the dangerous decline of the populations as a result of the unmanaged exploitation of this resource (AMORIM et al., 2009). This species is mainly caught by longlines as an important part of the commercial by-catch of the professional fishery targeting swordfish and tunas in the Atlantic Ocean (AMORIM et al., 2009). In the Mediterranean Sea incidental catches are also reported from artisanal fisheries (gill net, trammel net) (BAUCHOT, 1987), but the presence of this species in the area is scarcely documented and limited to sporadic records, maybe linked to possible misidentification with the common thresher A. vulpinus (CIGALA FULGOSI, 1983). This paper reports the first occurrence of the bigeye thresher in the northern part of the Mediterranean basin and a review of records known up to date in the Mediterranean area.

\section{MATERIAL AND METHODS}

The cephalic portion (including pectoral fins) of a specimen of $A$. superciliosus was landed at Camogli harbour (Ligurian Sea; Fig. 1) on $9^{\text {th }}$ September 2015. It was caught 16 miles far from the coast (Longitude $44^{\circ} 06^{\prime} \mathrm{N}$, 


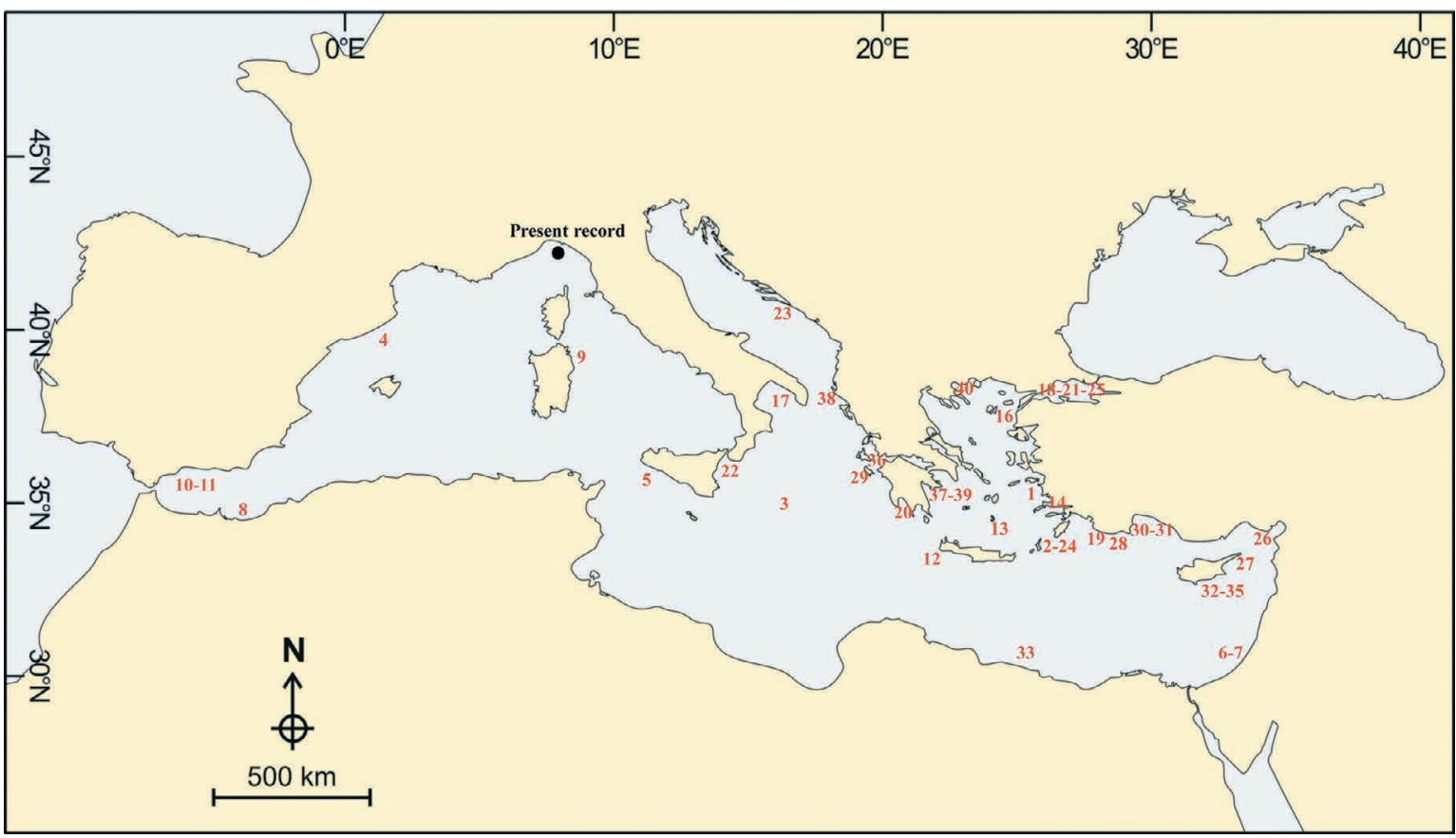

Fig. 1. Map of records of A. superciliosus in the Mediterranean Sea

Latitude $008^{\circ} 57^{\prime} \mathrm{E}$ ) by a mesopelagic swordfish longline (MESO SWOLL), which replaced the most commonly used surface swordfish long line (SWO LL) since 2010 (GARIBALDI, 2015a). Seventeen morphometric measures of the head and the pectoral fins were taken, in accordance with COMPAGNO (1984): head Length (HDL), prebranchial length (PGL), prepectoral fin length (PP1), pectoral fin length (P1L), pectoral fin height $(\mathrm{P} 1 \mathrm{H})$, pectoral-fin anterior margin $(\mathrm{P} 1 \mathrm{~A})$, pectoral fin posterior margin (P1P), pectoral fin inner margin (P1I), preorbital length (POB), eye height (EYH), eye length (EYL), interorbital space (INO), prenarial length (PRN), internarial space (INW), preoral length (POR), mouth width (MOW), mouth length (MOL). All measures are reported in Table 1.

Nine of these measures (PP1, P1A, POB, EYH, EYL, INW, POR, MOW, MOL; dependent variables, y) allowed to estimate the hypotethical total length (TL; independent variable $\mathrm{x}$ ) of the specimen by the mean of a length-length linear regression model $(y=a+b x$; Table 2$)$ derived by the measures taken on 13 worldwide distributed specimens analysed by GRUBER \& COMPAGNO (1981). Only the linear regression models showing a high Pearson's correlation coefficient
Table 1. Measurements (in $\mathrm{cm}$ ) of the present specimen

\begin{tabular}{lc}
\hline \multicolumn{1}{c}{ Measures } & $\begin{array}{c}\text { Length } \\
\text { (cm) }\end{array}$ \\
\hline Head Length (HDL) & 43.6 \\
Prebranchial length (PGL) & 31.6 \\
Prepectoral fin length (PPL) & 41.7 \\
Pectoral fin length (P1L) & 25.4 \\
Pectoral fin heigth (P1H) & 53.2 \\
Pectoral-fin anterior margin (P1A) & 54.4 \\
Pectoral fin posterior margin (P1P) & 50.6 \\
Pectoral fin inner margin (P1I) & 7.4 \\
Preorbital length (POB) & 11 \\
Eye height (EYH) & 7.4 \\
Eye length (EYL) & 4.7 \\
Interorbital space (INO) & 7.4 \\
Prenarial length (PRN) & 8.1 \\
Internarial space (INW) & 4.5 \\
Preoral length (POR) & 12.3 \\
Mouth width (MOW) & 10.4 \\
Mouth length (MOL) & 7.3 \\
\hline
\end{tabular}

$(r>0.8)$ were considered correlated; the significance of each variable was tested by means of analysis of variance with the Fisher test (p-value $=0.05$ ). 


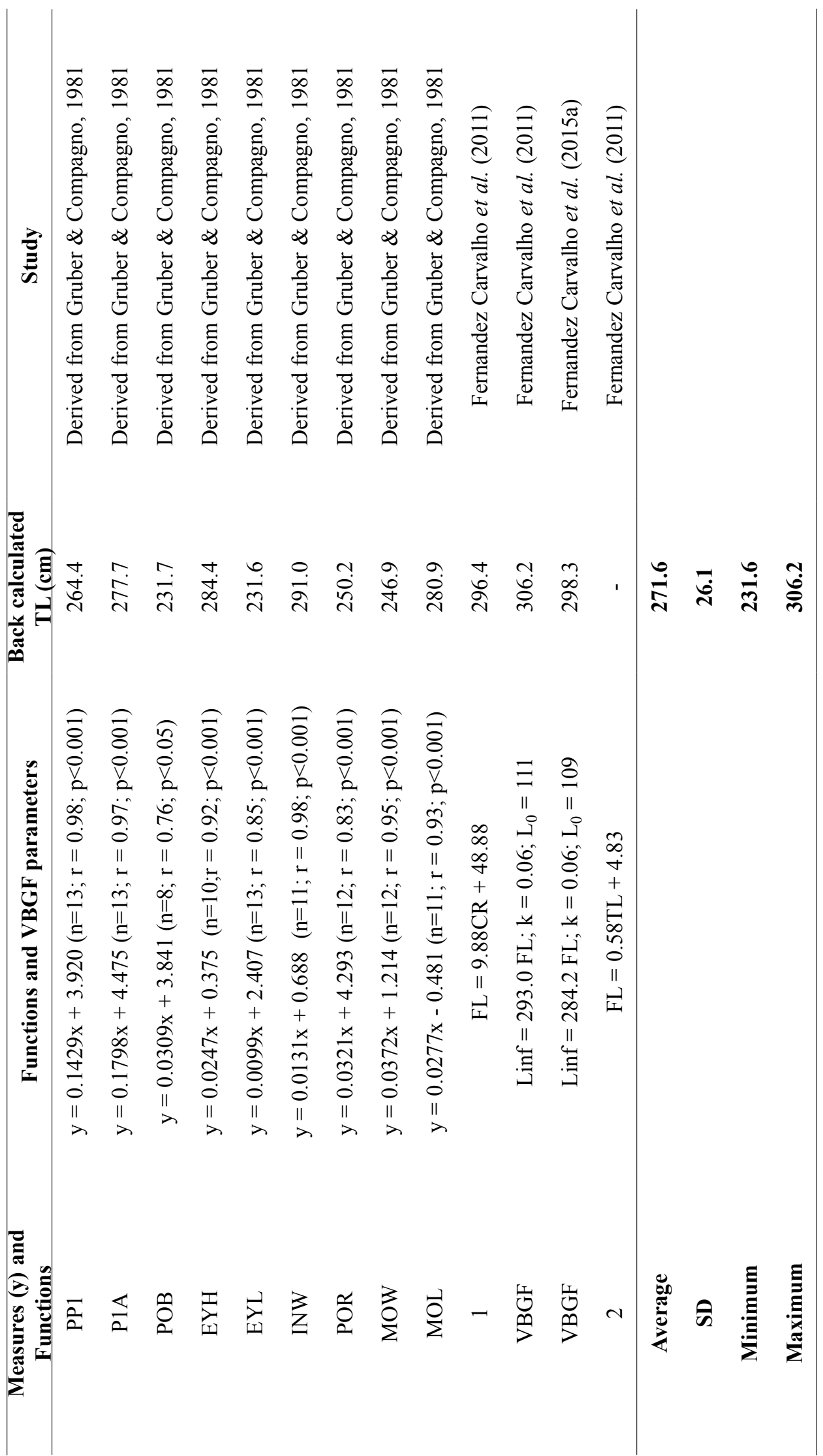


Sex and sexual maturity were determined macroscopically by the direct observation of the small gonadal portion found on the residual part of the trunk.

In order to estimate age of the specimen, a total of 7 undamaged cephalic vertebrae were collected, measured (centrum radius, CR) and later on sectioned on the sagittal plan by the means of an Buehler Isomet Low Speed Saw, obtaining $0.8 \mathrm{~mm}$ thick sections. For the enhancement of growth bands, some sections were coloured using a staining Methylen Blue solution $0.1 \%$. The vertebral sections were photographed and images digitalized. Age determination was performed counting the growth bands both on the whole vertebral centrum and sections. A supplementary estimate of the TL, starting to the fork length (FL), was performed by applying the von Bertalanffy growth function (VBGF): $L t=L_{\text {inf }}-\left(L_{\text {inf }}-L_{0}\right) e^{-k t}$, where $L_{t}$ $=$ mean length (FL) at age $t, L_{\text {inf }}=$ asymptotic maximum length (FL), $k=$ the growth coefficient, $L_{0}=$ length at birth, and the relationship between CR and TL reported by FERNANDEZCARVALHO et al. $(2011 ; 2015$ a) for the specimens of the Atlantic area (Table 2).

\section{RESULTS}

The particular morphology of the head (Fig. 2 ), with deep dorsal horizontal groove on each side and the vertical developed, large eyes allowed to distinguish A. superciliosus from the other two species belonging to the genus Alopias, the indigenous common thresher $A$. vulpinus and the pelagic thresher A. pelagicus (COMPAGNO, 1984).

The classification was also confirmed by jaw observation; teeth are similar in the upper and lower jaw, moderately large, showing slender, slightly curved cusps with smooth edges. No symphysial teeth are present. The dental formula (12-12/11-11; Fig. 3) corresponds to the commonest described in literature for the species (GRUBER \& COMPAGNO, 1981).

The cranial portion of the specimen was cut and ripped behind the pectoral fins, showing teeth and bite marks, probably due to a preda- tory/scavenging activity of a large shark (Fig. 2). The marks were not evident enough to allow a clear identification of the possible shark species involved in this scavenging activity. It could be reasonably due to a large blue shark (Prionace glauca) given that it is the commonest pelagic shark species in the Mediterranean and some evidences of scavenging activity on cetaceans, birds and some large pelagics (i.e. Bluefin tuna) were observed as a result of the stomach contents analysis in the same area (GARIBALDI \& ORSI RELINI, 2000).

The portion of gonadal tissue left inside the trunk after the scavenging activity was $28.3 \mathrm{gr}$ in weight. The presence of small oocytes, ranging in diameter between $0.5 \mathrm{~mm}$ and $2.08 \mathrm{~mm}$ allowed to determine it was a juvenile/subadult/ immature female, also taking into account that studies demonstrated that $A$. superciliosus has a

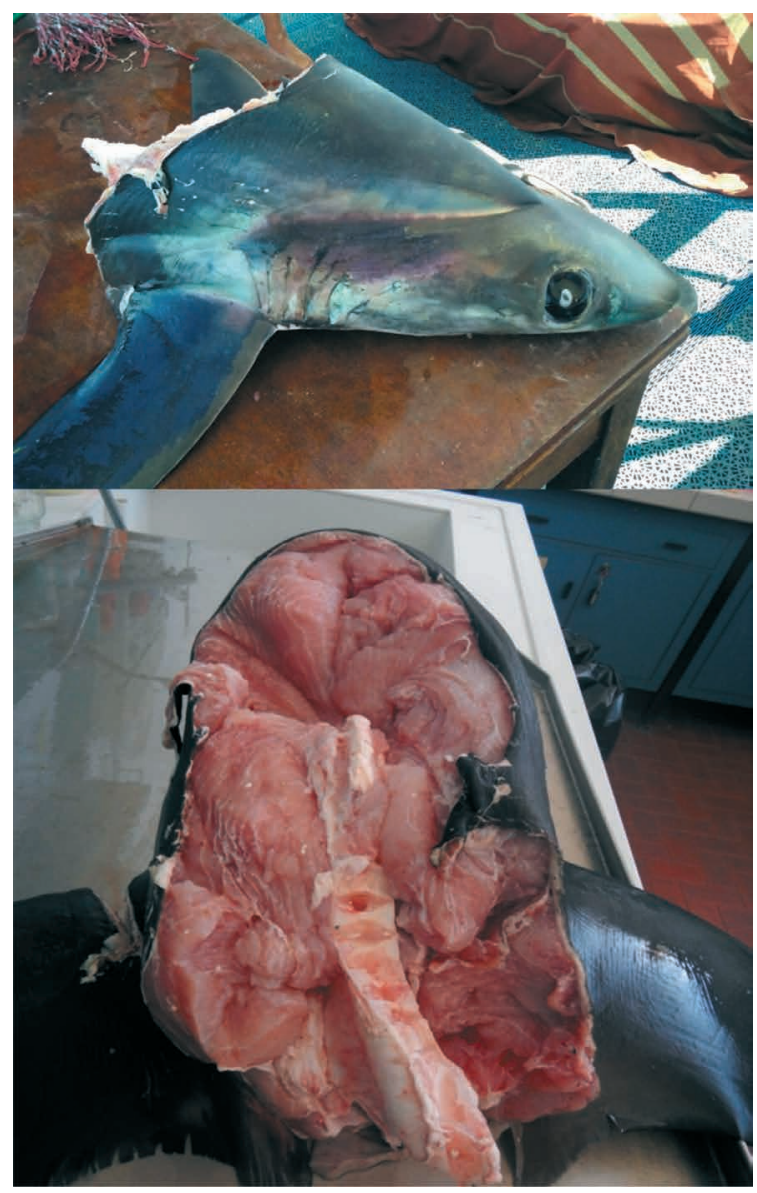

Fig. 2. Head of the present specimen as found by fishermen (upper photo courtesy of Renato Cammarata) 


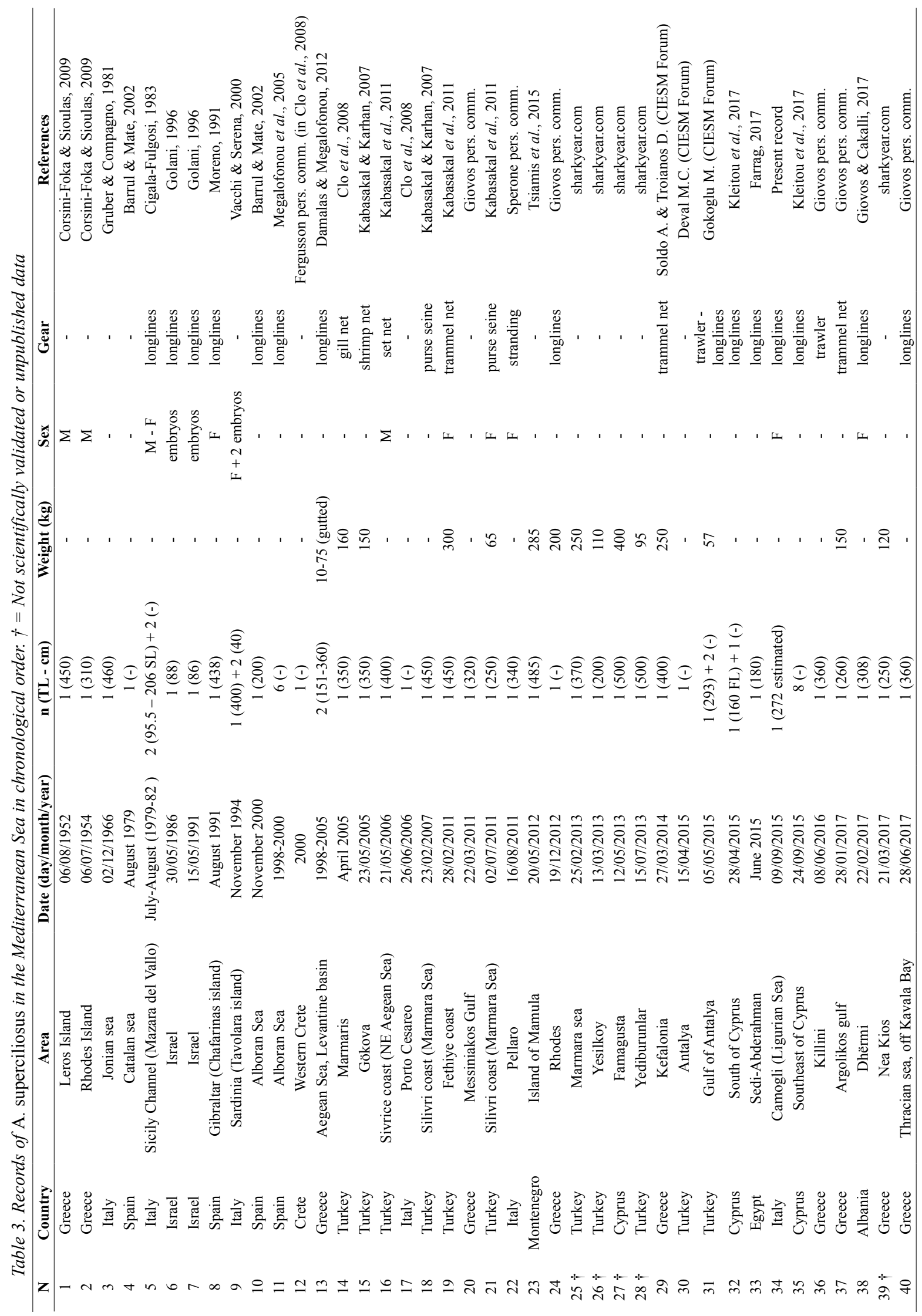




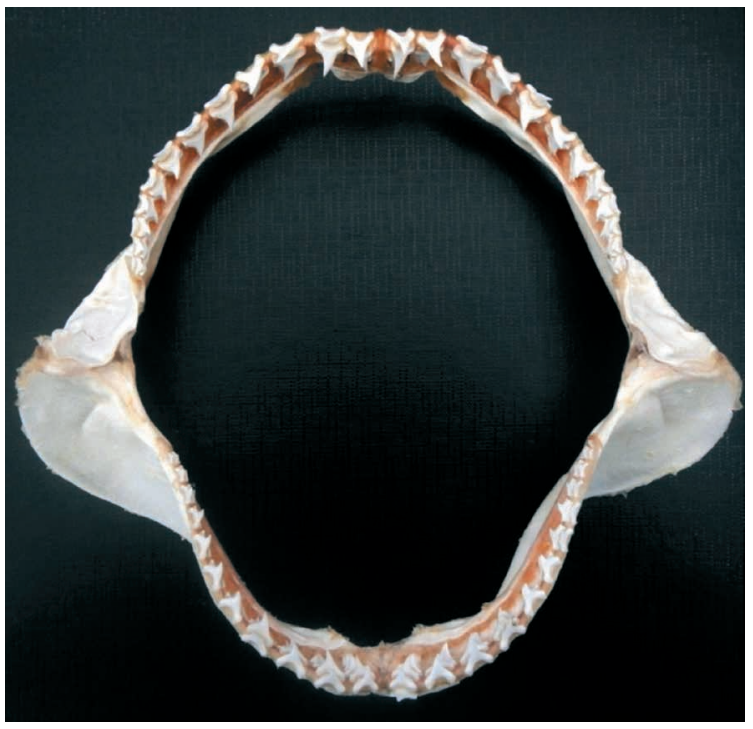

Fig. 3. Jaws of the present specimen of A. superciliosus

size-at-first maturity $\left(\mathrm{L}_{50}\right)$ between 332 and 350 $\mathrm{cm}$ TL, at about 12-13 years of age (STILLWELI \& CASEY, 1976; MORENO \& MORON, 1992; CHEN et al., 1997; FERNANDEZ CARVALHO et al., 2015a; b). The analysis of annual growth bands has led to an estimated age of 8 years (Fig. 4).

On the basis of all the above collected parameters, following the different methods reported in Table 2 was possible to estimate that the size of the specimen could be between 231.6 $\mathrm{cm}$ and $306.2 \mathrm{~cm} \mathrm{TL}$, an average size of 271.6 cm TL (st. dev. 26.1) (Table 2).

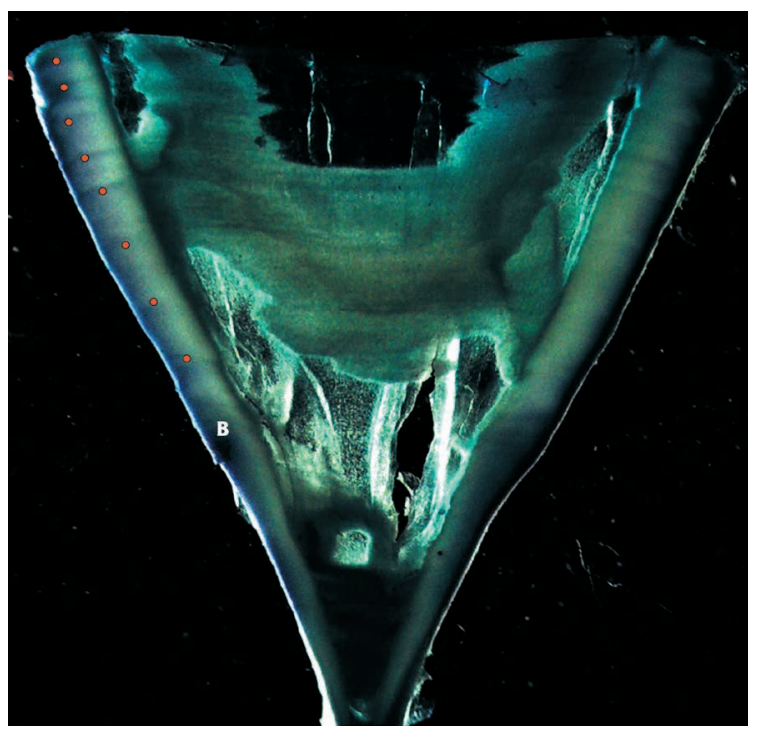

Fig. 4. Vertebral section. $B=$ birth band. Red dots= growth rings
Considering the linear regression models obtained from nine measures of the head and fins derived by GRUBER \& COMPAGNO (1981) the average estimated size was $262.1 \mathrm{~cm}$ TL $(\mathrm{SD}=22.8)$.

On the basis of the vertebral ring radius measure (average of $12.7 \mathrm{~mm}$; $\mathrm{SD}=0.33$ ) the size should correspond to an individual of 174.7 cm FL (296.4 cm TL; Table 2).

Considering the two VBGF reported for the Atlantic ocean by FERNANDEZ-CARVALHO et al. (2011; 2015a) an eight years old female should correspond to a specimen ranging form 175.8 and $180.4 \mathrm{~cm}$ FL (i.e. 298.3-306.2 cm TL) (Table 2).

\section{DISCUSSION}

The present record is the most northerly reported for this species in the Mediterranean and the sixth in Italian waters (CIGALA FULGOSI, 1983; VACCHI \& SERENA, 2000; CLÒ et al., 2008; SPERONE pers.comm.) (Table 3). The area comprising Ligurian and North Tyrrhenian sea is the bulk of the Pelagos Sanctuary, established for the protection of its ecosystem and cetaceans, officially recognized as Specially Protected Areas of Mediterranean Interest (SPAMI). It is often described as a "small ocean" for its oceanographic and biological characteristics and is a well known feeding area for many large apex predators, such as cetaceans (Mysticeti and Odontoceti), tunas, swordfish, billfishes and pelagic sharks, mainly from families Lamnidae, Alopiidae, Carcharinidae (ORSI RELINI et al., 1999; GARIBALDI \& ORSI RELINI, 2000), due to the presence of a permanent geostrophic frontal area and upwelling processes, sustaining a complex food web (GASPARINI et al., 1999). The presence of "alien" or non indigenous large pelagic species were recorded in the past as documented by the catches of a black marlin Makaira indica (ORSI RELINI \& COSTA, 1987) and a great hammerhead Sphyrna mokarran (BOERO \& CARLI, 1977), which are so far the only records for the Mediterranean Sea, and more recently of a silky shark, Carcharhinus falciformis (GARIBALDI \& ORSI RELINI, 2012). 
Unlike what observed for the common thresher, A. vulpinus, that more frequently is present in epipelagic water (CARTAMIL et al., 2010; CAO et al., 2011), the bigeye thresher shark is a species with strong diel vertical migration, diving over $900 \mathrm{~m}$ depth (COELHO et al., 2015). It spends the most of the daytime in deeper and cold mesopelagic waters between 300$500 \mathrm{~m}$ and the night-time in epipelagic waters between 10-100 m depth (WENG \& BLOCK, 2004; COELHO et al., 2015). This habit was confirmed by this catch; in fact the fishermen estimated by the counting of hooks that the specimen was caught with the MESOSWOLL at a depth around $300 \mathrm{~m}$, over a water column of $1000 \mathrm{~m}$ depth. In the Ligurian Sea over the last seven years the introduction of this gear completely changed the fishing pattern. Before 2010, with the traditional surface SWOLL the elasmobranchs by-catch represented more than $48 \%$ in numbers of the total catch with a massive presence of the pelagic stingray, Pteroplatytrigon violacea, $(43,7 \%)$, followed by the blue shark P. glauca, the shortfin mako Isurus oxyrinchus, the porbeagle shark Lamna nasus, the common thresher A. vulpinus and certain species belonging to the family Carcharhinidae (Carcharhinus plumbeus and C. falciformis) were recorded in the area. On the contrary, using MESO SWOLL elasmobranch by-catch of the swordfish fishery is normally composed only by $P$. glauca, the little sleeper shark Somniosus rostratus and, at a smaller extent, by the pelagic stingray, with a strong reduction of discards and commercial bycatch of elasmobranchs species, which is at present less than $10 \%$ in numbers of the total catch (GARIBALDI, 2015b). The differences between the two gears are referred to timing of fishing operations (SWO LL 8-10 hours, MESO SWOLL 24-36 hours), but mainly to the depth of displacement (SWO LL 0-20 m depth, MESO SWO LL 100-600 m depth) (GARIBALDI, 2015a).

Despite the increase of the fishing effort recorded for the MESO SWOLL in the Ligurian sea and generally in all the Western Mediterranean area, with a consequent major overlap with the main habitat of the A. superciliosus (COELHO et al., 2015), the documented catches by longlines of this species in the Mediterranean are not increasing over the last 15 years (Table 3 ), suggesting that it can be considered rare in the area. In the last decades the majority of the records for this species in the Mediterranean have been reported from the south eastern basin (Greek and Turkish waters), as confirmed by the numerous catches reported by longlines fleet of Cyprus (KLEITOU et al., 2017) and some more recent records not yet reported in the scientific literature (Fig. 1; Table 3). This could be linked to environmental factors influencing shark movements and migrations (SCHLAFF et al., 2014), such as temperature, salinity, water depth, bottom topography and food availability (WENG \& BLOCK, 2004, PRETI et al., 2008; CAO et al., 2011; COELHO et al., 2015).

A possible source of bias could be related to other factors, such as the misidentification or its low commercial value, if compared with the common thresher A. vulpinus and, in past, frequently discarded onboard (CIGALA FULGOSI, 1983; AMORIM et al., 2015). Nevertheless, with the introduction of the recent EC Regulation which have forbidden the retaining onboard or the landing of $A$. superciliosus (Council Reg. $2017 / 127$ of 28/01/2017), fishermen are also inclined to reject the specimens at sea, avoiding possible sanctions. For the future, in order to improve the knowledge on the distribution of this species in the Mediterranean, it would be useful to encourage fishermen to report and take documentation (i.e. photographs) of any catches, before releasing the specimens caught.

\section{ACKNOWLEDGEMENTS}

We would like to thank the fisherman $\mathrm{Mr}$. RENATO CAMMARATA who preserved the specimen for the analysis, Dr. FABRIZIO SERENA who provided the data from MEDLEM project, Dr. EMILIO SPERONE for the data of the specimen stranded in Pellaro, iSea (Non Profit Non-Governmental Organisation for the Preservation of the Aquatic Ecosystems) and IOANNIS GIOVOS for some new records reported in Greece and Albania. 


\section{REFERENCES}

AMORIM, A., J. BAUM, G.M. CAILLIET, S. CLÒ, S.C. CLARKE, I. FERGUSSON, M. GONZALEZ, D. MACIAS, P. MANCINI, C. MANCUSI, R. MYERS, M. REARDON, T. TREJO, M. VACCHI \& S.V. VALENTI. 2009. Alopias superciliosus. The IUCN Red List of Threatened Species 2009: http://dx.doi.org/10.2305/IUCN.UK.2009-2. RLTS.T161696A5482468.en.

BAUCHOT, M.L. 1987. Raies at autres batoides. In: M. Fisher et al. (Editors). Fiches FAO d'Identification des Especs pour les Besoins de la Peche. Mediterranee et Mer Noire. Zone de Peche 37. Revision 1. II, FAO, Rome, pp. 847-885.

BARRULL, J. \& MATE I. 2002. Tiburones del Mediterraneo. Arenys de Mar: Libreria El Setciències.

BOERO, F. \& C. CARLI C. 1977. Prima segnalazione mediterranea di Sphyrna mokarran (Rüppel,1837) (Selachii, Sphynidae). Boll. Mus. Ist. Biol. Univ. Genova, 45: 91-93.

CAO, D.M, L.M SONG, Y. ZHANG, K.K LV \& Z.X. HU. 2011. Environmental preferences of Alopias superciliosus and Alopias vulpinus in waters near Marshall Islands. N. Z. J. Mar. Freshwater Res., 45(1): 103-119.

CARTAMIL, D., D.N.C. WEGNER, S. AALBERS, C.A. SEPULVEDA, A. BAQUERO, J.B. GRAHAM. 2010. Diel movement patterns and habitat preferences of the common thresher shark (Alopias vulpinus) in the Southern California. Mar. Fresh. Res., 61: 596-604.

CAVANAGH, R.D., \& C. GIBSON. 2007. Overview of the conservation status of cartilaginous fishes (Chondrichthyans) in the Mediterranean Sea. Gland, Switzerland and Malaga, Spain: IUCN.

CHEN, C.T., K.M. LIU, \& Y.C. CHANG. 1997. Reproductive biology of the bigeye thresher shark, Alopias superciliosus (Lowe, 1939) (Chondrichthyes: Alopiidae), in the northwestern Pacific. Ichthyol. Res., 44(3): 227-235.

CIGALA FULGOSI, F. 1983. First record of Alopias superciliosus (Lowe, 1839) in the Mediterranean, with notes on some fossil species of the genus Alopias. Ann. Mus. Civ. St. Nat. Genova, 84: 211-229.
CLO', S., R. BONFIL \& E. DE SABATA. 2008. Additional records of the bigeye thresher shark, Alopias superciliosus, from the central and eastern Mediterranean Sea. JMBA2, Biodiversity Records.

COELHO, R., J. FERNANDEZ-CARVALHO \& M.N. SANTOS. 2015. Habitat use and diel vertical migration of bigeye thresher shark: Overlap with pelagic longline fishing gear. Mar. Environ. Res., 112(B): 91-99.

COMPAGNO, L.J.V. 1984. FAO species catalogue. Vol. 4. Sharks of the world. An annotated and illustrated catalogue of shark species known to date. Part 1. Hexanchiformes to Lamniformes. Rome: FAO. FAO Fisheries Synopsis, n.125, 249 pp.

CORSINI-FOKA, M. \& A. SIOULAS. 2009. On two old specimens of Alopias superciliosus (Lowe, 1839) (Chondrichthyes: Alopiidae) from the Aegean waters. Mar. Biodiversity Rec., 2; e72.

DAMALAS, D. \& P. MEGALOFONOU. 2012. Occurrences of large sharks in the open waters of the southeastern Mediterranean Sea. J. Nat. Hist. 46(43-44): 2701-2723.

FARRAG, MMS. 2017. New record of the bigeye thresher shark, Alopias superciliosus Lowe, 1841 (Family: Alopiidae) from the eastern Mediterranean Sea, Egypt. Int. J. Fish. Aquat. Stud., 5(2): 316-318.

FERNANDEZ-CARVALHO, J., R. COELHO, K. ERZINI \& M.N. SANTOS. 2011. Age and growth of the bigeye thresher shark, Alopias superciliosus, from the pelagic longline fisheries in the tropical northeastern Atlantic Ocean, determined by vertebral band counts. Aquat. Living Resour., 24: 359-368.

FERNANDEZ-CARVALHO, J., R. COELHO, K. ERZINI \& M.N. SANTOS. 2015a. Modeling age and growth of the bigeye thresher (Alopias superciliosus) in the Atlantic Ocean. Fish. Bull., 113 (4): 468-481.

FERNANDEZ-CARVALHO, J., R. COELHO, J. MEJUTO, E. CORTES, A. DOMINGO, K. YOKAWA, K.M. LIU, B. GARCÍA-CORTES, R. FORSELLEDO, S. OHSHIMO, A. RAMOS-CARTELLE, W-PEI. TSAI \& M.N. SANTOS. 2015b. Pan-Atlantic distribu- 
tion patterns and reproductive biology of the bigeye thresher, Alopias superciliosus. Rev. Fish. Biol. Fisheries, 25(3): 551-568.

FROESE, R., \& D. PAUlY. 2016. FishBase. World Wide Web electronic publication. www.fishbase.org, version (10/2016).

GARIBALDI, F. 2015a. Effects of the introduction of the mesopelagic longline on catches and size structure of swordfish in the Ligurian sea (western Mediterranean). Col. Vol. Sci. Pap., ICCAT, 71 (5): 2006-2014.

GARIBALDI, F. 2015b. By catch in the mesopelagic swordfish longline fishery in the Ligurian Sea (North Western Mediterranean). Col. Vol. Sci. Pap., ICCAT, 71(3): 1495-1498.

GARIBALDI, F. \& L. ORSI RELINI. 2000. Abbondanza estiva, taglie e nicchia alimentare della verdesca nel Santuario Pelagico del Mar Ligure. Biol. Mar. Mediterr., 7(1): 324-333.

GARIBALDI F. \& L. ORSI RELINI. 2012. Record of Carcharhinus falciformis (Bibron in Müller \& Henle, 1839), in Italian waters (Ligurian Sea, Northwestern Mediterranean). Cybium, 36(2): 399-400.

GASPARINI, G.P., G. ZODIATIS, M. ASTRALI, C. GALLI \& S. SPARNOCCHIA. 1999. Winter intermediate water lenses in the Ligurian Sea. J. Mar. Sys., 20: 319-332.

GIOVOS, I., \& M. CAKALLI 2017. The first record of the Bigeye Thresher Alopias superciliosus in Albanian waters. Collective A., Medit. Mar. Sci. (in press).

GOLANI, D. 1996. The marine ichthyofauna of the eastern Levant - history, inventory and characterization. Isr. J. Zool., 42: 15-55.

GRUBER, S.H., \& L.J.V. COMPAGNO. 1981. Taxonomic status and biology of the bigeye thresher, Alopias superciliosus (Lowe, 1839). Fish. Bull., 79: 617-640.

KABASAKAL, H., \& S.U. KARHAN. 2008. On the occurrence of the bigeye thresher shark, Alopias superciliosus (Chondrichthyes: Alopiidae), in Turkish waters. Marine Biodiversity Records, 1. doi: 10.1017/ S1755267207007452.

KABASAKAL, H., C. DALYAN \& A. YURTSEVER. 2011. Additional records of the bigeye thresher shark Alopias superciliosus (Lowe, 1839)
Chondrichthyes: Lamniformes: Alopiidae) from Turkish waters. Annales, Ser. Hist. Nat., 21: 143-148.

KLEITOU, P., C. ANTONIOU C., I. GIOVOS I., \& D. KLETOU. 2017. How accurately are we describing the longline bycatch? The case of the 'rare' shark Alopias superciliosus in eastern Mediterranean. Int. J. Fish. Aquat. Stud., 5(3): 375-378.

MEGALOFONOU, P., C. YANNOPOULOS, D. DAMALAS, G. DE METRIO, M. DEFLORIO, J.M. DE LA SERNA \& D. MACIAS. 2005. Incidental catch and estimated discards of pelagic sharks from the swordfish and tuna fisheries in the Mediterranean Sea. Fish. Bull., 103: 620634.

MORENO, J.A. 1991. Lamnidae and Alopiidae (Chondrichtyes Euselachii) del Atlantico Noroccidental y Mediterraneo occidental: sistemàtica, biologia y aspectos pesqueros. Tesis doctoraòl, Universidad Complutense de Madrid.

MORENO, J.A \& J. MORON. 1992. Reproductive biology of the bigeye thresher shark, Alopias superciliosus (Lowe, 1839). Aust. J. Mar. Freshw. Res., 43: 77-86.

ORSI RELINI, L., \& M.R. COSTA. 1987. Cattura di un Marlin a Camogli: segnalazione di Makaira indica (Cuvier 1832) (Osteichthyes, Istiophoridae) nel Mediterraneo. Doriana, suppl. Ann. Mus. Civ. St. Nat. Genova, 6(259): 1-4.

ORSI RELINI, L., G. PALANDRI, F. GARIBALDI \& C. CIMA. 1999. Longline swordfish fishery in the Ligurian Sea: eight years of observations on target and by-catch species. Col. Vol. Sci. Pap., ICCAT, 49(1): 146-150.

PRETI, A.P., S. KOHIN, H. DEWAR \& D. RAMON. 2008. Feeding habits of the bigeye thresher (Alopias superciliosus) sampled from the California-based drift gillnet fishery. CalCOFI Report, 49: 202-211.

SCHLAFF, A.M., M.R. HEIPEL \& C.A. SIMPFENDORFER. 2014. Influence of environmental factors on shark and ray movement, behaviour and habitat use: a review. Rev. Fish Biol. Fisheries, 24: 1089-1103.

STILLWELI, C.E., \& J.G. CASEY. 1976. Observations on the bigeye thresher shark, Alopias super- 
ciliosus, in the western North Atlantic. Fish. Bull., 74: 221-225.

TSIAMIS, K., Ö. AYDOGAN, N. BAILLY, P. BALISTRERI, M. BARICHE, S. CARDEN-NOAD M. CORSINI FOKA, F. CROCETTA, B. DAVIDOV, C. DIMITRIADIS, B. DRAGIČEVIĆ, M. DRAKULIĆ , J. DULČIĆ, A. ESCÁNEZ, F.A. FERNÁNDEZÁLVAREZ, V. GERAKARIS , V. GEROVASILEIOU , R. HOFFMAN, D. IZQUIERDO-GÓMEZ, A. IZQUIERDO-MUÑOZ, G. KONDYLATOS, P. LATSOUDIS, L. LIPEJ, F. MADIRACA, B. MAVRIČ, M. PARASPORO, L. SOURBÈS, E. TAŞKIN, A. TÜRKER \& S. YAPICI. 2015. New Mediterranean Biodiversity Records (July 2015). Medit.
Mar. Sci., 16/2: 472-488.

VACCHI, M., \& F. SERENA. 2000. On a large specimen of bigeye thresher shark Alopias superciliosus (Lowe, 1839) (Chondrichthyes: Alopiidae) stranded in Tavolara Island (Eastern Sardinia, Mediterranean). Séret, B. and Sire, J.-Y. (eds). Proceedings of the $3^{\text {rd }}$ European Elasmobranch Association Meeting, Boulogne-sur-47 Mer (France), 1999. Soc. Fr. Ichtyol and IRD Paris, 3, p. 84.

WENG, K.C. \& B.A. BLOCK. 2004. Diel vertical migration of the bigeye thresher shark (Alopias superciliosus), a species possessing orbital retia mirabilia. Fish. Bull., 102 (1): 221-229.

Received: 16 June 2017

Accepted: 11 August 2017 


\title{
Novi nalaz velikookog psa lisice, Alopias superciliosus Lowe, 1841, u sjeverozapadnom Sredozemlju s pregledom svih dosadašnjih nalaza u Sredozemlju
}

\author{
Luca LANTERI*, Laura CASTELLANO i Fulvio GARIBALDI \\ *Kontakt, e-adresa: luca.lanteri@libero.it
}

\begin{abstract}
SAŽETAK
Dana 9. rujna 2015. godine pronađena je glava morskog psa roda Alopias u luci Camogli na Ligurskom moru (sjeverozapadni Mediteran). Primjerak glave je ulovljen 16 milja daleko od obale (44

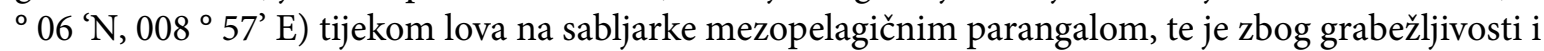
uklanjanja drugih primjeraka morskih pasa, utvrđena samo glava. Primjerak glave je pripadao ženki morskog psa Alopias superciliosus, koji spada u visoko migratorne vrste rasprostranjene širom svijeta $\mathrm{u}$ tropskim i umjerenim vodama, no rijetko su ulovljene u Sredozemnom moru.

Ovaj je nalaz najsjeverniji za ovu vrstu u Sredozemlju i ujedno je šesti nalaz za talijanske vode.
\end{abstract}

Ključne riječi: Alopias superciliosus, Ligusko more, Sredozemno more, prilov, parangal 
